DOI: https://doi.org/10.31933/jemsi.v2i3

Received: 20November2020, Revised: 15 Desember2020, Publish: 8 Februari 2021

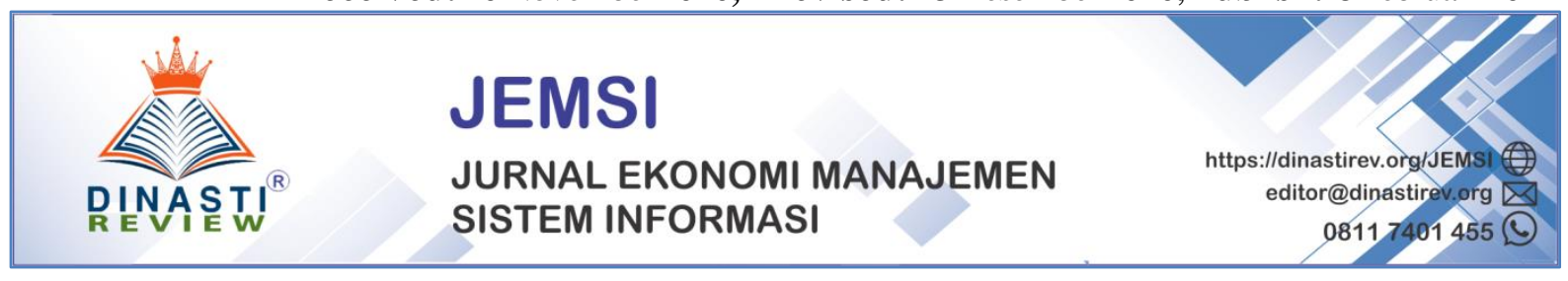

\title{
PENGARUH MOTIVASI, KEPEMIMPINAN, KOMPETENSI, DAN KEDISIPLINAN TERHADAP KINERJA SERTA KEPUASAN KERJA ASN
}

\author{
Muhammad Badrun \\ Mahasiswa Program Magister Management, Universitas Terbuka, Jakarta. Email, \\ muhbadrun1980@gmail.com
}

Corresponding Author: Muhammad Badrun

Abstrak: Penulisan ini menggunakan metode kuantitatif yang bertujuan untuk mengetahui
hubunganantara dan kinerja gurudi SMK NEGERI 2 KOTA BIMA. Hipotesis yang diajukan
dalam penulisanini adalah adahubungan positif antara dan kinerja guru. Semakin tinggi
maka semakin tinggi pulakinerja guru, demikian pula sebaliknya.Adapun subjek dalam
penulisan ini berjumlah 20 guru di SMK NEGERI 2 KOTA BIMA'. Metode skala menjadi
metode pilihan untuk mengungkap kompetensi dan kinerja guru, melaluiskala kompetensi
dan skala kinerja guru. Analisis data menggunakan teknik Korelasi Product Momentmelalui
SPSS for Wind ows versi 20.0.Hasil penulisan menunjukkan bahwa tidak ada hubungan
yangsignifikan antara kompetensi dan kinerja guru yang dibuktikan dengan nilai $\mathrm{r}$ SMK
Negeri 2 Kota Bima y $=-0,428$ dan $\mathrm{p}=0,012(\mathrm{p}<0.01)$, sehingga hipotesis yang dinyatakan
dalam penulisan ini ditolak.

Kata kunci: kinerja guru, kompetensi.

\section{PENDAHULUAN}

\section{Latar Belakang}

Di Negara Kita Republik Indonesia, berbagai regulasi dan pedoman terkait peningkatan kinerja aparatur negara pada kementerian / lembaga dan pemerintah daerah telah diterbitkan Undang-undang Nomor 42 Tahun 1999 perubahan atas Undang-Undang No 8 tahun1974 tentang Pokok-pokok Kepegawaian diperkuat dengan Peraturan Menteri Pendayagunaan Aparatur Negara dan Reformasi Birokrasi Republik Indonesia Nomor 17 Tahun 2017 tentang Pedoman Penilaian Kinerja. Selain itu, berdasarkan Peraturan Pemerintah (PP) Nomor 20 Tahun 2019 tentang Penilaian Kinerja Pegawai Negeri Sipil (PNS) atau sekarang dikenal dengan ASN yang telah ditetapkan pada 26 April 2019, sistem penilaian kinerja pegawai negeri sipil (PNS) masuk dalam paradigma baru dengan unsur yang lebih komprehensif dan obyektif. Tidak hanya sebatas kepribadian, tetapi juga kinerja yang sukses dengan standar tertentu. Dengan adanya SKP (Sasaran Kinerja Pegawai / Sasaran Kinerja Pegawai) diharapkan akan ada peningkatan kompetensi dan profesionalisme aparatur sipil negara dalam menjalankan tugas dan fungsinya sebagai aparatur masyarakat Setiap organisasi memiliki tata cara, adat, dan juga regulasi masing-masing. dalam mencapai tujuan 
dan misi organisasi, termasuk cara individu berinteraksi satu sama lain (bersosialisasi), dan cara individu mengatasi masalah yang dihadapi oleh organisasi.

Keyakinan tersebut dijadikan sebagai asumsi dasar yang mendasari semua program, strategi dan perencanaan kegiatan sehingga menghasilkan nilai yang tinggi karena kegiatan yang dilakukan tidak melanggar apa yang telah diprogramkan, begitu pula sebaliknya. Penyelenggara negara harus memiliki karakteristik tertentu seperti keterampilan dan kecakapan yang tinggi, wawasan dan pengetahuan yang komprehensif, bakat dan potensi, kepribadian dan motif kerja, serta moral dan etos kerja yang tinggi. Kinerja yang berkualitas menunjukkan kualitas profesional, sebaliknya kinerja yang rendah menunjukkan kegagalan dalam menghormati profesinya sendiri. Aparatur sipil negara sebagai unsur aparatur negara dalam penyelenggaraan program kebangsaan menjadi penanggung jawabnya kualitas kinerja yang rendah menunjukkan kegagalan dalam menghormati profesinya sendiri. Aparatur sipil negara sebagai unsur aparatur negara dalam penyelenggaraan program kebangsaan menjadi penanggung jawabnya kualitas kinerja yang rendah menunjukkan kegagalan dalam menghormati profesinya sendiri. Aparatur sipil negara sebagai unsur aparatur negara dalam penyelenggaraan program kebangsaan menjadi penanggung jawabnya

Peraturan Pemerintah Nomor 52 Tahun 2010 tentang Disiplin Pegawai Negeri Sipil (PNS). Disiplin PNS adalah kemampuan aparatur sipil negara untuk menaati kewajibannya dan menghindari larangan yang diatur dalam Undang-Undang Dasar dan / atau peraturan resmi. Seolah tidak ditaati atau dilanggar, mereka akan diberi hukuman disiplin. Dengan korelasi dengan bekerja, bekerja disiplin adalah keadaan hormat, penghargaan, ketaatan, dan kepatuhan terhadap aturan yang diperoleh baik tertulis maupun tidak tertulis. Juga mampu menerapkan aturan dan tidak terhindar dari sanksi ketika melanggar tugas dan kewenangan yang diberikan.

Dokumen laporan supervisi akademik selama satu tahun pembelajaran menunjukkan bahwa sebagian ASN masih kurang memiliki dorongan untuk menguasai tantangan dalam mengajar, kurang berkembang dan belum mendapatkan yang terbaik dalam proses pembelajaran. Sebagian guru mengalami kesulitan dalam pembuatan silabus dan rencana pelaksanaan pembelajaran, kurangnya kedisiplinan yang ditekankan kepada guru seperti guru datang terlambat dan menunda masuk kelas dengan berbagai alasan, penggunaan metode dan strategi pembelajaran, menyusun alat-alat evaluasi, kegiatan pengelolaan kelas, dan kurangnya kemampuan dalam menentukan pendekatan dan cara-cara evaluasi dalam proses belajar mengajar. 
Fakta di lapangan yang menunjukkan masih rendahnya kinerja ASN. antara lain: guru tidak membuat perencanaan yang memadai dalam menjalankan tugas mengajar, tidak menyusun RPP, membuat RPP hanya untuk memenuhi syarat administrasi mengajar dan tidak mempersiapkan media pembelajaran. Ada juga guru yang mengajar dengan acuan buku.Semua fakta di atas menggambarkan masih rendahnya kinerja ASN, sebagai insan yang mengemban tugas profesional, kinerjanya masih perlu mendapatkan perhatian.

\section{a. Tujuan Penelitian}

Untuk menganalisis pengaruh variabel motivasi, kepemimpinan, kompetensi, dan kedisiplinan terhadap kinerja dan kepuasan kerja pegawai

\section{b. Rumusan Masalah}

1. Apakah motivasi berpengaruh terhadap kinerja ASN?

2. Apakah kepemimpinan berpengaruh terhadap kinerja ASN?

3. Apakah kompetensi berpengaruh terhadap Kinerja ASN?

4. Apakah kedisiplinan berpengaruh terhadap Kinerja ASN?

5. Apakah motivasi berpengaruh terhadap kepuasan kerja ASN?

6. Apakah kepemimpinan berpengaruh terhadap kepuasan kerja ASN?

7. Apakah kompetensi berpengaruh terhadap kepuasan kerja ASN?

8. Apakah kedisiplinan berpengaruh terhadap kepuasan kerja ASN?

\section{KAJIAN PUSTAKA}

\section{Motivasi (Y1)}

Stooner (1992) mendefinisikan bahwa motivasi adalah sesuatu hal yang menyebabkan dan yang mendukung tindakan atau perilaku seseorang. Knootz (1972) merumuskan bahwa motivasi mengacu pada dorongan dan usaha untuk memuaskan kebutuhan atau suatu tujuan (Motivation refers to the drive and efford to satisfy a want or goal). Sedangkan Hasibuan merumuskan bahwa motivasi adalah suatu perangsang keinginan (want) dan daya penggerak kemajuan bekerja seseorang. Ia menambahkan bahwa setiap motif mempunyai tujuan tertentu yang ingin dicapai (Notoatmodjo, 2007).

Ada beberapa ahli psikologis membagi motivasi dalam beberapa tingkatan, namun secara umum terdapat keseragaman dalam mengklasifikasikan tingkatan motivasi, yaitu: 
1) MotivasiKuat: Motivasidikatakankuat apabila dalam diri seseorang memiliki keinginan yang positif, mempunyai harapan yang tinggi, dan memiliki keyakinan yang tinggi bahwa dirinya akan berhasil dalam mencapai tujuan dan keinginannya.

2) MotivasiSedang: Motivasidikatakansedang apabila dalam diri seseorang memiliki keinginan yang positif, mempunyai harapan yang tinggi, namun memiliki keyakinan yang rendah untuk berhasil dalam mencapai tujuan dan keinginan.

3) Motivasi Lemah: Motivasi dikatakan lemah atau rendah apabila di dalam diri seseorang memiliki keinginan yang positif namun memiliki harapan dan keyakinan yang rendah bahwa dirinya dapat mencapai tujuan dan keinginannya. (Irwanto, 2007).

Tujuan motivasi adalah untuk menggerakkan atau menggugah seseorang agar timbul keinginan dan kemauannya untuk melakukan sesuatu sehingga dapat memperoleh hasil atau mencapai tujuan tertentu. Dalam mencapai tujuan motivasi, maka setiap orang yang akan memberikan motivasi harus mengenal dan memahami benar-benar latar belakang kehidupan, kebutuhan, dan kepribadian orang yang akan dimotivasi (Purwanto, 2007).

\section{Kepemimpinan}

Pemimpin yang menerapkan jenis kepemimpinan situasional lebih sering menyesuaikan setiap gaya kepemimpinan yang ada dengan tahap perkembangan para anggota yakni sejauh mana kesiapan dari para anggota melaksanakan setiap tugas. Pemimpin harus memiliki pemahaman yang jujur mengenai siapa dirinya sendiri. Kesuksesan seorang pemimpin sejati berasal dari pengakuan pengikut atau masyarakat, oleh karena itu untuk menjadi sukses, seorang pemimpin harus meyakinkan pengikutnya dan dia harus mampu menampilkan sosok yang layak untuk diikuti.

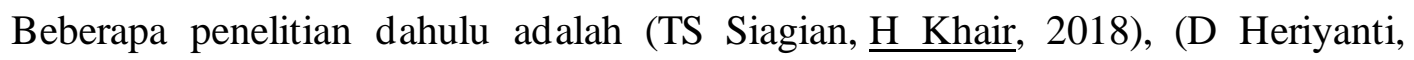
2007), (Agung Widhi Kurniawan, 2012), (Ratna Kusumawati, 2018), (Rachmat SUkarja, Machasin, 2015), (Sri Rustilah, 2018).

Secara umum, seorang pemimpin (leader) memiliki aura karismatik di dalam dirinya, memiliki visi misi yang jelas, mampu mengendalikan apa yang dipimpin, dan tentunya pandai dalam berkomunikasi. Pemimpin adalah individu yang melakukan proses mempengaruhi sebuah kelompok atau organisasi untuk mencapai sesuatu tujuan yang telah disepakati bersama. 
Sedangkan kepemimpinan adalah sifat yang diterapkan individu yang bertindak sebagai pemimpin untuk mempengaruhi anggota kelompoknya untuk mencapai sasaran dan tujuan yang telah disepakati bersama.

Beberapa sifat yang biasanya melekat pada diri seorang pemimpin, diantaranya adalah sebagai berikut.

1. Intelejensi - Kemampuan bicara, menafsir, dan bernalar yang lebih kuat daripada para anggota yang dipimpin.

2. Kepercayaan Diri - Keyakinan akan kompetensi dan keahlian yang dimiliki

3. Determinasi- Hasrat untuk menyelesaikan pekerjaan yang meliputi ciri seperti berinisiatif, kegigihan, mempengaruhi, dan cenderung menyetir

4. Integritas - Kualitas kejujuran dan dapat dipercaya oleh para anggota

5. Sosiabilitas - Kecenderungan pemimpin untuk menjalin hubungan yang menyenangkan, bersahabat, ramah, sopan, bijaksana, dan diplomatis. Menunjukkan rasa sensitif terhadap kebutuhan orang lain dan perhatian atas kehidupan mereka.

\section{Kompetensi}

tandar Kompetensi Guru adalah beberapa indikator yang dapat dijadikan ukuran karakteristik guru yang dinilai kompeten secara profesional.[1] Kompetensi guru merupakan perpaduan antara kemampuan personal, keilmuan, teknologi, sosial, dan spiritual yang secara menyeluruh membentuk kompetensi standar profesi guru, yang mencakup penguasaan materi, pemahaman terhadap peserta didik, pembelajaran yang mendidik, pengembangan pribadi, dan profesionalisme.[1]

Guru merupakan komponen paling utama dalam sistem pendidikan secara keseluruhan yang harus mendapatkan perhatian yang maksimal. Figur ini akan mendapat sorotan strategis ketika berbicara masalah pendidikan, karena guru selalu terkait dengan komponen manapun dalam sistem pendidikan.[1] Guru mempunyai peran yang sangat strategis dalam upaya mewujudkan tujuan pembangunan nasional, khususnya di bidang pendidikan, sehingga perlu dikembangkan sebagai tenaga profesi yang bermartabat dan profesional.[1]

Berdasarkan standar kompetensi ini, seorang guru harus memiliki empat kompetensi yaitu:[2] 
Kompetensi profesional, yaitu kecakapan seorang guru dalam mengimplementasikan halhal yang terkait dengan profesionalisme yang terlihat dalam kemampuannya mengembangkan taanggung jawab, melaksanakan peran dengan baik, berusaha mencapai tujuan pendidikan, dan melaksanakan perannya dalam pembelajaran di kelas.

Kompetensi pedagogik yaitu menguasai dan memahami karakter serta mengidentifikasi potensi dan kesulitan belajar siswa. Guru juga harus mampu mengembangkan kurikulum sehingga mampu mebuat rancangan pembelajaran yang menarik dan memanfaatkaan teknologi dan informasi untuk kepentingan pendidikan.

Kompetensi sosial, yaitu kemampuan guru dalam berinteraksi dengan siswa, orang tua siswa, rekan seprofesi dan lingkungan, baik secara langsung maupun tidak langsung.

Kompetensi kepribadian, yaitu kemapuan menjadi teladan akan sikap sikap positif.

Siswa memiliki keinginan agar mereka lebih mudah dalam memahami pelajaran. Hal ini bisa terlaksana apabila guru memiliki kemampuan berikut ini [2]:

Mampu melibatkan peserta didik dalam proses pembelajaran, mampu memperlakukan mereka secara adil dan mampu membedakan perbedaan setiap peserta didik

Mampu menguasai bidang ilmu yang diajarkan, dan mengaitkannya dengan pelajaran lain serta menghubungkannya dengan dunia nyata

Mampu menciptakan, memperkaya dan menyesuaikan metode mengajar yang menarik minat siswa

Dalam banyak analisis tentang kompetensi keguruan, aspek kompetensi kepribadian dan kompetensi sosial umumnya disatukan.[4]

Rincian kompetensi personal sosial yang disarankan dalam uraian ini adalah:

a. Mampu menghayati serta mengamalkan nilai hidup (nilai moral dan keimanan)

b. Jujur dan bertanggung jawab

c. Mampu berperan menjadi pemimpin

d. Bersikap bersahabat, terampil berkomunikasi

e. Mampu berperan aktif dalam pelestarisan dan pengembangan budaya 
f. Mampu bersahabat dengan siapapun tanpa menghilangkan prinsip dan nilai hidup yang diyakini

g. Mampu berperan dalam kegiatan sosial

h. Bermental sehat dan stabil

i. Mampu tampail secara pantas dan rapi

j. Kreatif dan penuh perhitungan

k. Mampu bertindak tepat tepat waktu dalam relasi sosial dan profesionalnya

1. Mampu menggunakaan waktu luang secara bijaksana dan produktif

Menurut Samana (1994:61-68), 10 kemampuan dasar guru adalah sebagai berikut:[4]

Guru dituntut menguasai bahan ajar

Guru mampu mengelola program belajar mengajar

Guru mampu mengelola kelas

Guru mampu menggunakan media dan sumber pembelajaran

Guru menguasai landasan landasan pendidikan (Ilmu Pendidikan, Psikologi Pendidikan, Administrasi Pendidikan dan Filsafat Pendidikan)

Guru mampu mengelola interakksi belajar mengajar

Guru mampu menilai prestasi belajar siswa untuk kepentingan pengajaran

Guru mengenal fungsi dan program pelayanan bimbingan dan penyuluhan

Guru mengenal dan mampu ikut serta dalam penyelanggaraan administrasi sekolah

Guru memahami prinsip-prinsip penelitian pendidikan dan mampu menafsirkan hasil penelitian pendidikan demi kepentingan pengajaran.

\section{Disiplin Kerja}

Disiplin kerja sebagai sikap hormat, hormat, dan ketaatan terhadap ketentuan yang berlaku baik tertulis maupun tidak tertulis serta mampu melaksanakannya, tidak mengelak sanksi jika melanggar tugas dan wewenang yang diberikan kepadanya. Disiplin kerja merupakan salah satu bentuk pengendalian diri karyawan dan pelaksanaan secara teratur serta menunjukkan tingkat kesungguhan tim kerja dalam suatu organisasi. Disiplin kerja yang baik mengacu pada besarnya rasa tanggung jawab seseorang terhadap tugas yang diberikan kepadanya. Disiplin yang tidak bersumber dari hati nurani manusia akan mengakibatkan disiplin yang lemah dan tidak langgeng. Penerapan disiplin kerja bagi karyawan bertujuan untuk mendorong karyawan agar mau dan mau mengikuti berbagai 
standar atau aturan yang berlaku di suatu perusahaan, sehingga penyalahgunaan pekerjaan dapat diatasi (Arenofsky, 2017).

Disiplin yang baik pada dasarnya akan tumbuh dan muncul dari hasil kesadaran manusia. Disiplin yang baik mencerminkan besarnya tanggung jawab seseorang atas tugas-tugas yang diberikan kepadanya, hal ini mendorong semangat kerja, semangat kerja, dan realisasi tujuan organisasi. Disiplin yang baik dari karyawan juga akan menunjukkan bahwa organisasi dapat menjaga dan menjaga loyalitas dan kualitas karyawannya, dari disiplin tersebut juga dapat diketahui nilai kinerja karyawannya. Secara umum disiplin kerja dapat dilihat jika karyawan datang ke kantor secara teratur dan tepat waktu, berpakaian rapi di tempat kerja, menggunakan peralatan kantor dengan hati-hati, menghasilkan jumlah dan kualitas pekerjaan yang memuaskan dengan mengikuti cara kerja yang ditentukan oleh perusahaan dan menyelesaikan pekerjaan dengan baik dan baik. memiliki semangat kerja yang tinggi (Webb et al., 2012)

Beberapa Penelitian terdahulu yaitu (EM Sutanto, DI Suwondo,2015), (A Susanty,

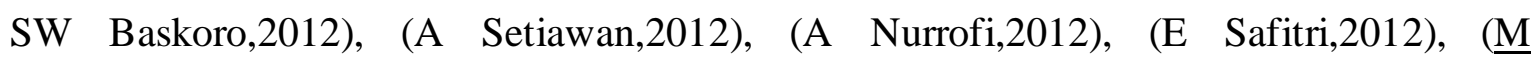
Harlie,2012), ( $\underline{\text { Z Hidayat }}, \underline{M}$ Taufiq,2012), (RA REZA,2010), (PM Sahangggamu,2015),

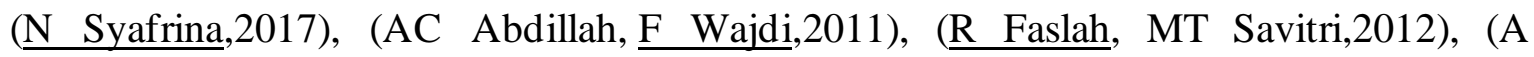
Kusnan,2005), (I Wiratama, DK Sintaasih,2012), (JN Liyas, R Primadi,Al-Masraf,2017),

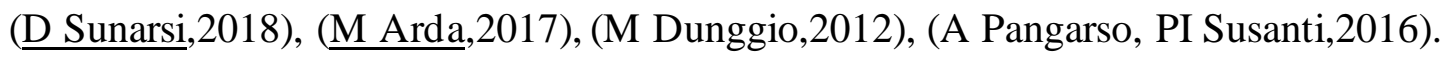

\section{Kinerja}

Pengertian kinerja (prestasi kerja) adalah kualitas dan kuantitas pekerjaan yang dicapai oleh seorang pegawai dalam menjalankan fungsinya sesuai dengan tanggung jawab yang diberikan kepadanya. Menurut (Al Mehrzi dan Singh, 2016) Kinerja adalah hasil atau tingkat keberhasilan seseorang secara keseluruhan selama kurun waktu tertentu dalam melaksanakan tugas dibandingkan dengan berbagai kemungkinan, seperti standar kerja, target atau target atau kriteria yang telah ditentukan sebelumnya telah disepakati bersama. Selanjutnya (Yang et al., 2016) menyatakan bahwa kinerja pada dasarnya adalah apa yang dilakukan atau tidak dilakukan oleh karyawan. Manajemen kinerja adalah seluruh aktivitas yang dilakukan untuk meningkatkan kinerja suatu perusahaan atau organisasi, termasuk kinerja masing-masing individu dan kelompok kerja yang ada di dalam perusahaan. Menurut (Shmailan, 2016) kinerja karyawan merupakan suatu tindakan yang dilakukan karyawan dalam melaksanakan pekerjaan yang dilakukan oleh perusahaan. 
Kinerja dalam menjalankan fungsinya tidak independen, tetapi selalu berkaitan dengan kepuasan kerja karyawan dan tingkat reward yang diberikan, serta dipengaruhi oleh keterampilan, kemampuan, dan sifat individu.

Menurut Simanjutak dalam Widodo (2015:122) kinerja dipengaruhi oleh: a. Kualitas dan kemampuan pegawai, hal-hal yang berhubungan dengan pendidikan/pelatihan, etos kerja, motivasi kerja, sikap mental, dan kondisi fisik pegawai. b. Sarana pendukung, yaitu hal yang berhubungan dengan lingkungan kerja (keselamatan kerja, kesehatan kerja, sarana produksi, teknologi) dan hal yang berhubungan dengan kesejahteraan pegawai (upah/gaji, jaminan sosial, keamanan kerja) c. Supra sarana, yaitu hal-hal yang berhubungan dengan kebijaksanaan pemerintah dan hubungan industrial manajemen.

Kinerja sudah banyak di teliti oleh peneliti sebelumnya diantaranya adalah: (Tomy Sun Siagian \& Hazmanan Khair,2018) (Wimpy Mulia,2012), (I Wayan Bayu Sandiartha \& I Gusti Made Suwandana,2020), (Agus Hery Priatna \& Made Subudi,2016), (Wero Juni Diastuti,2014), (Hamsinah DKk,2017), (Endit Jaloe Prasetyo,dkk,2020), (Abdul Aziz,2020) (Gusti Bagus AriPinatih \& A.A.A.Eddy Supriyadinata Gorda,2017), (Faizatur Rohma dkk,2019), (Mauli Siagian\& Wasiman,2020),(Viska Yanti,2020),(Tomy Sun Siagian \& Hazmanan Khair,2018), (Made Bayu Sumarjaya\&Iwayan Gede Supartha,2017), (Roeselandro Eddy Nugroho,2019), (Novita Angela Mamahit,2016), (Desi Rosmala Dewi DKK,2017), (Dina Rochmana Sari,2012), (Dian Riseki Finarty Dkk,2016), (I Gede Sudha Cayana\&I ketut Jati,2017), (Putra Arif Simanjuntak,2020), (Chadek Novi Charisma dewi Dkk,2018), (Rani Mariam,2009), (Geri Surto Sukmono,2020), (Amrozi 2014), (Muhammad Fauzan Baihaqy,2010), (Komarudin,2018), (Ferni Wijaya,2017)

\section{Kepuasan Kerja}

Kepuasan kerja adalah tingkat kesenangan yang dirasakan seseorang atas peranan atau pekerjaannya dalam organisasi. Tingkat rasa puas individu bahwa mereka mendapat imbalan yang setimpal dari bermacam-macam aspek situasi pekerjaan dari organisasi tempat mereka bekerja. Jadi kepuasan kerja menyangkut psikologis individu didalam organisasi, yang diakibatkan oleh keadaan yang ia rasakan dari lingkungannya.

T. Hani Handoko (2000: 192-194) mengemukakan bahwa kepuasan kerja (Job Satisfaction) adalah keadaan emosional yang menyenangkan atau tidak menyenangkan dengan para karyawan memandang pekerjaan mereka. Waktu/lama penyelesaian 
merupakan pencerminan perasaan seseorang terhadap pekerjaannya. Ini dapat dilihat dari sikap positif karyawan terhadap pekerjaan dan segala sesuatu di lingkungannya.

Beberapa Penelitian terdahulu yaitu (Chadek Novi Charisma dewi Dkk,2018), (Wimpy Mulia,2012), (Geri Surto Sukmono,2020), (Amrozi,2014), (I Wayan Bayu Sandiartha \& I Gusti Made Suwandana,2020), (I Gede Sudha Cayana \&I ketut Jati,2017), (Putra Arif Simanjuntak,2020), (Rani Mariam,2009),(Mauli Siagian\& Wasiman,2020), (Viska Yanti,2020), Musa Jamaludin,2009), (GA Wijaya, MS Ma'arif, $\underline{\mathrm{A}}$ Sukmawati,2014), A Dwi Nugroho, K Kunartinah, 2012), M Harlie, 2012), (TAM Engkun,2018), (B Suhariyanto, 2016), (A Muslim, S Sutinah,2020), (EPL Krissetyanti,2012)

Tingkat kepuasan kerja adalah merupakan salah satu faktor yang mempengaruhi prestasi kerjanya karena yang akhirnya berpengaruh pada efektivitas organisasi. Dan juga kepuasan kerja pegawai tidak cukup hanya diberikan insentif saja akan tetapi pegawai juga membutuhkan motivasi, pengakuan dari atasan atas hasil pekerjaannya, situasi kerja yang tidak monoton dan ad anya peluang untuk berinisiatif dan berkreasi.

\section{Kerangka konseptual}

Kerangka konseptual ini sepenuhnya menggambarkan korelasi langsung antara variabel pengembangan karir (X 1) dan disiplin kerja (X 2) menuju kepuasan kerja (Y 1) dan kinerja ASN (Y 2) ada SMKN 2 Kota Bima, Variabel tersebut adalah variabel laten yang tidak dapat diukur. Oleh karena itu pengukurannya menggunakan indikator yang dapat dilihat pada kerangka konseptual di bawah ini: 


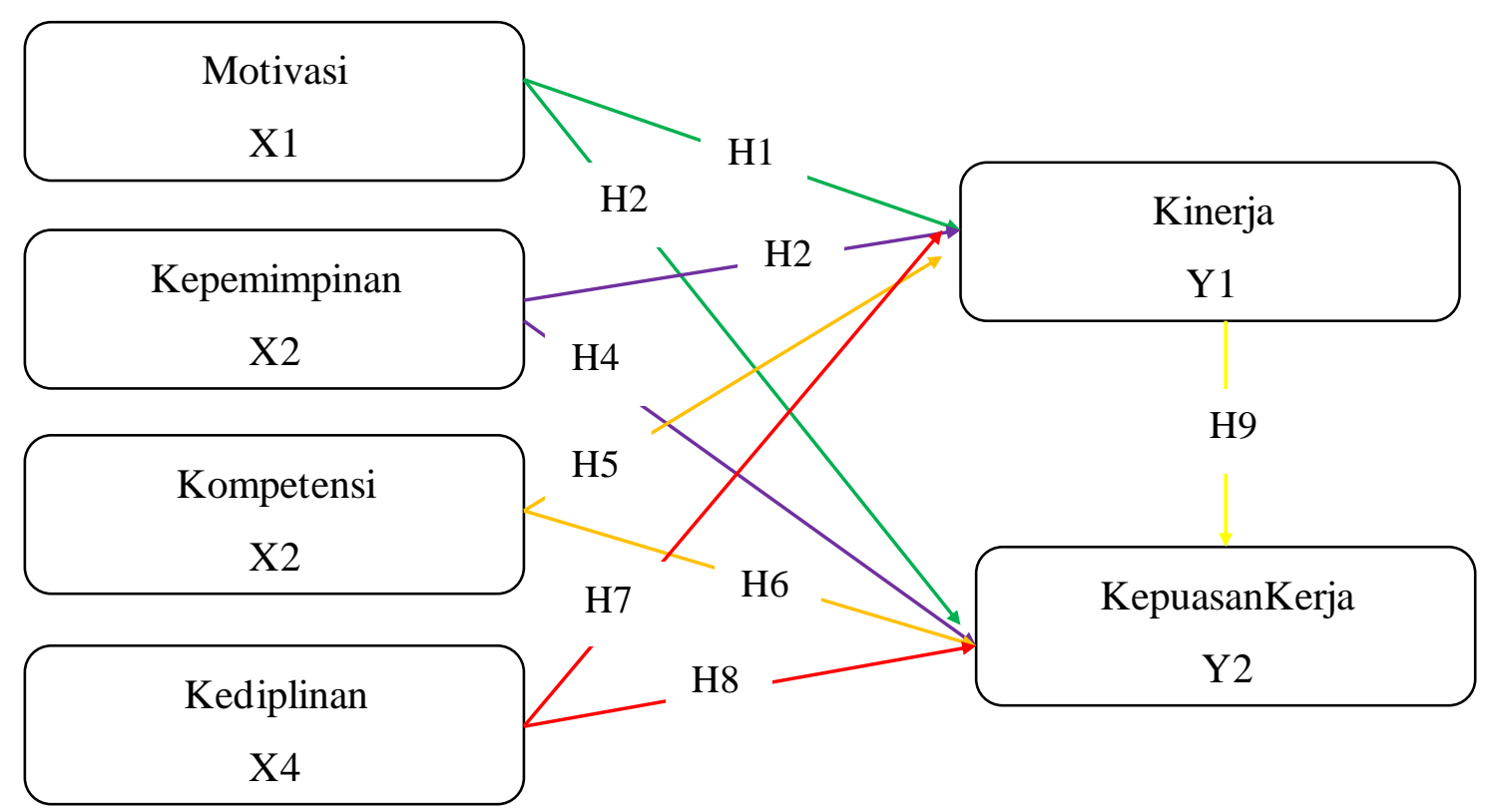

\section{Gambar kerangka konseptual penelitian}

\section{METODE PENULISAN}

Metode penulisan artikel ini adalah metode kuantitatif, meneari pengaruh antara Variabel bebas (Independent Vuriable) dengan Variabel terikat (Dependent Variable). Variabel dalam penelitian ini mehputi variabel independent ( variabel bebas) yang terdiri dari variable budaya organisasi (XI). komitrnen guru (X2), dan variable motivasi kerja ( X2) dan variable dependent ( variable terikat) yaitu variable $k$ inerja guru ( $\mathrm{Y}$ ). Populasi dalam penelitian ini adalah seluruh guru SMK Negeri 2 Kota BIma. Penentuan sampel menu rut Suharsirni Arikunto (2006 : 121) bahwa apabila subyek kurang dari 100. maka lebih baik diam bi I semua sehingga penelitiannya terrnasuk penelitian populasi. Jumlah guru SMK Negeri 2 Kota Bima adalah sebanyak 60 orang, maka sarnpel yang diambil dalam penelitian ini adalah sebanyak 60 orang guru.

lnstrurnen Penelitian di kembangkan oleh peneliti berdasarkan indikator-indikator dan teori-teori yang mendukung, kemudian indikator ini akan di gunakan sebagai kisi-kisi instrument dan dilanjutkan menyusun instrument pengukuran dalarn bentuk kuesioner yang rnenyajikan pertanyaan fakta guru dengan jawaban skala Liken dengan kisaran 1-5 yang di buat

Dalam bentuk eheekhst . Presedur pengumpulan data yang digunakan dalam penelitian ini baik data mengenai budaya organisasi, komitmen guru. rnotivasi kerja dan kinerja guru adalah menggunakan angket I Kuesioner. Sedangkan analisis data dengan menggunakan editing, K,Ordinf, Seoring, dan Tabulating.. kemudian dilakukan uji validitas sehingga menghasilkan data yang valid

\section{Pengaruh Motivasi dan kepemimpinan}

Hasil hasil analisis deskriptif rnenunjukkan bahawa keecendrungan pengaruh budaya organisasi terhadap kinerja guru SMK negeri 2 Kota Bima dalarn kategori tinggi. 
Berdasarkan hasil analisis diketahui bahwa terjadi pengaruh antara budaya organisasi terhadap kinerja guru. Hal ini dibuktikan dengan uji Regression diketahui bahwa ada pengaruh positif budaya organisasi terhadap kinerja guru di SMK negeri 2 Kota Bima. maka penelitian ini berhasil mernbuktikan hipotesis pertama yang menyatakan bahwa "Ada pengaruh budaya organisasi terhadap kinerja guru di SMK negeri 2 Kota Bima ".

Budaya organisasi sekolah atau iklim sekolah ( fisik dan non fisik ) yang kondusif akademik rnerupakan prasyarat bagi terselenggaranya proses belajar mengajar yang efektif. ( direktorat Pembinaan Sekolah Menengah Pertarna, Diknas, 2006 ). Lingkungan sekolah yang aman dan tertib, optimisme dan harapan/ekspektasi yang tinggi dari warga sekolah, kesehatan sekolah dan kegiatan yang berpusat pada siswa adalah eontoh-eontoh budaya sekolah yang dapat menurnbuhkan semangat belajar siswa. Budaya sekolah sudah merupakan kewenangan sekolah sehingga yang di perlukan upaya - upaya yang lebih intensif dan ekstensif demi produktivitas sekolah. Standar yang hams dimiliki kepala sekolah, Dede (2004: 229) menjelaskan bahwa, kepala sekolah sebagai seorang menajer hams memiliki dua kriteria yaitu pengetahuan teknis dan keterampilan manajerial. Pengetahuan teknis meliputi kemampuan yang dapat meningkatkan kualitas pembelajaran yang baik, quality control, model evaluasi pembelajaran, pengembangan alat belajar pengetahuan tentang keuangan, tentang inventarisasi dan administrasi personalia. Keterampilan manajerial adalah keterampilan yang mengarah pada semua anggota organisasi untuk mengerjakan tugas sesuai dengan bidang dan kewenangannya

Dalam meningkatkan kinerja guru diharapkan sekali peran seorang kepala sekolah sebagai orang yang bertanggungjawab dalam meneiptakan budaya atau iklim sekolah bersama dengan guru dan personil sekolah lainnya. Kepala sekolah diharapkan mampu menjalani tugas dalam mengkoordinir personil yang ada di lingkungan sekolah serta memenuhi kriteria yang hams dipunyai sebgai seorang meneger sebuah lembaga pendidikan serta memenuhi syarat sebagaimana yang telah diatur dalam Peraturan Pemerintah No 12 tahun 2007. Apabila semua ini sudah dijalani secara baik dan benar maka iklim sekolah dapat berjalan secara kondusif. Budaya atau iklim sekolah yang kondusif akan berpengaruh terhadap kinerja guru Merupakan suatu hal yang harus diperhitungkan dalam dunia pendidikan karena kinerja guru tersebut sangat erat kaitannya dengan fenomena fenomena sosial yang terjadi saat ini dan Budaya sekolah merupakan salah satu factor dalam meningkatkan kinerja guru. Walaupun besar pengaruh budaya sekolah dalam penelitian ini hanya berpengaruh 40,2\% terhadap kinerja guru namun ini bisa ditingkatkan bila kepala sekolah mampu meneiptakan budaya sekolah yang kondusif. Begitu juga dengan guru, lingkungan sekolah ,nilai nilai sosial dan budaya organisasi sekolah dapat dijadikan sebagai media untuk meningkatkan kinerja guru.

\section{Pengaruh Komitmen Guru terhadap Kinerja guru}

Hasil analisis deskritif menunjukkan bahawa kecendrungan kinerja guru SMK Negeri 2 Kota Bima dalam kategori. Berdasarkan hasil analisis diketahui bahwa terjadi pengaruh antara komitmen guru terhadap kinerja guru. Hal ini dibuktikan dengan uji Regression diketahui bahwa ada pengaruh positif budaya organisasi terhadap kinerja 
guru di SMK negeri 2 Kota Bima. Kajian literatur ini berhasil membuktikan hipotesis pertama yang menyatakan bahwa "Ada pengaruh komitmen guru terhadap kinerja guru di SMK negeri 2 Kota Bima ",

Menurut Van Dyne dan Graham (dalam Eoetzee, 2005) ada beberapa faktor yang mempengaruhi komitmen organisasi seseorang. Faktor-faktor yang mempengaruhi komitmen organisasi tersebut antara lain faktor personal situasional, dan positional. Dalam faktor situasional terdapat beberapa hal yang disebutkan mempengaruhi komitmen organisasi yaitu karakteristik guru dan dukungan sekolah.

Sedangkan Menurut Beggs dan Kohut (dalam Eoetzee, 2005) ada beberapa karakteristik guru yang membuat pekerja berkomitmen tinggi terhadap organisasi. Karakteristik guru tersebut antara lain kepuasan tehadap otonomi, status dan kepuasan pada permintaan organisasi, sehingga seorang guru akan merasa bertanggung jawab dan keterikatan dengan organisasinya. Sedangkan karakteristik guru yang menunjukkan adanya komitmen yang rendah adalah pekerjaan yang memiliki rutinitas yang tinggi.

Dukungan organisasi sendiri menurut Eoetzee (2007) sangat penting agar guru mau memberikan waktu yang Jebih untuk organisasi. Dukungan yang dapat diberikan oleh organisasi kepada pekerjanya dapat berupa kemudahan untuk menyeimbangan antara tanggung jawab pekerjaan dan tanggung jawab keluarga mereka. Dengan kata lain apabila guru merasa bahwa perannya di dalam suatu organisasi tidak akan mengganggu perannya didalam keluarga, maka guru tersebut akan memiliki komitmen organisasi yang tinggi.

Merupakan suatu hal yang harus diperhitungkan dalam dunia pendidikan karena kinerja guru tersebut sangat erat kaitannya dengan fenomena fenomena sosial yang terjadi saat ini dan komitmen guru merupakan salah satu faktor dalam meningkatkan kinerja guru. Walaupun pengaruh komitmen guru dalam penelitian ini hanya berpengaruh 52,1 \% terhadap kinerja guru namun ini bisa ditingkatkan bila kepala sekolah memiliki komitmen terhadap sekolahnya. Begitu juga dengan guru, lingkungan sekolah ,nilai nilai sosial dan komitmen guru dapat dijadikan sebagai media untuk meningkatkan kinerja guru

\section{Conceptual Framework}

Berasarkan kajian teori dan huubungan antara variable maka model atau Eoneeptual Framework artikel ini dalam rangka membangun hipotesis adalah sebagai berikut:

Penelitian yang mendukung penelitian ini adalah penelitian yang dilakukan oleh:

1. Influenee of Organizational Eommitment. Transaetional Leadership, and Servant Leadership to the Work Motivation, Work Satisfaetion and Work Performanee of

Teaehers at Private Senior 1 ligh Sehools in Surabaya menernukan bahwa kornitrnen organisasional berpengaruh signifikan terhadap kinerja guru. Hasil riset Wahyuni et al (2014)

2. Ade et al. (2013) dalarn fhe Influenee of Organizational Eommitment and Individual Eompetenee on Teaeher Performanee. Mereka mengatakan bahwa 
komitmen organisasional berpengaruh positif dan signifikan terhadap kinerja guru.

3. MeNeese-Smith( 1996) dengan variabel Dependen: Kinerja karyawan Independen.Produktivitas. kepuasan kerja, komitmen organisasi rnenernukan bahwa kornitrnen organisasi berhubungan positif dengan kinerja karyawan.

4. Sunamo (2012) dalam yayasan Pendidikan Kesatriaan menemikan bahwa Budaya organisasi berpengaruh positif dan signifikan terhadap kinerja guru di SMk Negerri 3 Kota Bima.

5. Sulairnan (2002) dalam variable devenden kinerja pegawai dan indevenden kornitrnen organisasi rnenemukan : kornitmen organisasi berhubungan positif dengan kinerja karyawan

Dari bebeapa kajian yang ikemukakan oleh beberapa ahli dan berdasarkan hasil penelitian dalam artikel ini maka diperoleh kerangka berrpikir artikel sebagaiberikut

\section{HIPOTESIS}

Berdasarkan Kajian teori dan hubungan antar variabel maka model atau Conceptual Framework artikel ini dalam rangka membagunan hipotesis adalah sebagai berikut:

1) Pengaruh Pengembangan Karir terhadap Kepuasan Kerja ASN berdasarkan hasil riset : (A Akhmal, F Laia, RA Sari , 2018), (S Bahri, YC Nisa,2017), (V Lisdiani, N Ngatno 2017)

2) Pengaruh Pengembangan Karir terhadap Kinerja ASN berdasarkan hasil riset: (R Rahmah, B Semmaila, S Serang,2020), (S Nurvitasari, B Semmaila, 2020),(CP Manurung,2020)

3) Pengaruh Disiplin Kerja terhadap Kepuasan Kerja ASN berdasarkan hasil riset : (ID Afianto, $\underline{\mathrm{HN} \quad \text { Utami}}, 2017), \quad(\mathrm{MDS} \quad$ Lumentut, $\underline{\mathrm{LOH}} \quad$ Dotulong,2015), $(\underline{\mathrm{AB}}$

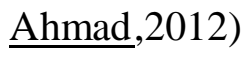

4) Pengaruh Disiplin Kerja terhadap Kinerja ASN berdasarkan hasil riset: (D Marlius,

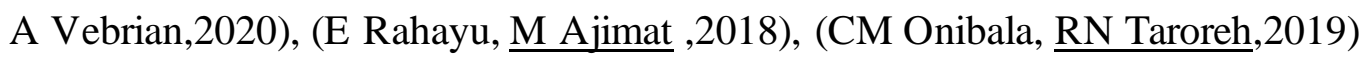

5) Pengaruh Kepuasan Kerja terhadap Kinerja ASN berdasarkan hasil riset : (I Syahputra, J Jufrizen \&Maneggio,2019), (R Rosmaini\& (Hermawan \&Maneggio,2019)

\section{KESIMPULAN}

Berdasarkan rumusan artikel, hasil dan pembahasan, maka dapat di di rumuskan hipotesis untuk riset selanjutnya:

1. Pengembangan Karir berpengaruh terhadap Kepuasan Kerja ASN 
2. Pengembangan Karir berpengaruh terhadap Kinerja ASN

3. Disiplin Kerja terhadap berpengaruh Kepuasan Kerja ASN

4. Disiplin Kerja terhadap berpengaruh Kinerja ASN

5. Kepuasan Kerja berpengaruh terhadap Kinerja ASN

\section{DAFTAR PUSTAKA}

Afianto, I. D., \& Utami, H. N. (2017). PENGARUH DISIPLIN KERJA DAN KOMUNIKASI ORGANISASI TERHADAP KEPUASAN KERJA DAN KINERJA KARYAWAN (Studi pada Karyawan Divisi Marketing PT. Victory International Futures Kota Malang). Jurnal Administrasi Bisnis S1 Universitas Brawijaya, 50(6), 58-67.

A.W. Dapu. Valensia. 2015. The Influence Of Work Discipline, Leadership, And Motivation On Employee Performance At Pt. Trakindo Utama Manado. Jurnal: EMBA Vol.2 No.2 Sept. 2015, Hal.252-261

Bahri, S., \& Chairatun Nisa, Y. (2017). Pengaruh Pengembangan Karir Dan Motivasi Kerja Terhadap Kepuasan Kerja Karyawan. Jurnal Ilmiah Manajemen Dan Bisnis, 18(1). https://doi.org/10.20596/jimb.v18i1.1295

Darmawan, I. (2017). PENGARUH IKLIM ORGANISASI DAN PENGEMBANGAN KARIR TERHADAP KOMITMEN ORGANISASI DAN KEPUASAN KERJA. Jurnal Dakwah Risalah, 28(2), 76. https://doi.org/10.24014/jdr.v28i2.5545

Dewi, N., \& Utama, I. (2016). PENGARUH PENGEMBANGAN KARIR TERHADAP KINERJA KARYAWAN MELALUI MEDIASI MOTIVASI KERJA PADA KARYA MAS ART GALLERY. E-Jurnal Manajemen Universitas Udayana, 5(9), 254949.

Gelar, M., Psikologi, S., Psikologi, P. S., \& Sampeliling, F. H. (2007). KEPUASAN KERJA KARYAWAN Skripsi, 08, 29-29.

Handoko, D. S., \& Rambe, M. F. (2018). Pengaruh Pengembangan Karir dan Kompensasi terhadap Komitmen Organisasi Melalui Kepuasan Kerja. Maneggio: Jurnal Ilmiah Magister Manajemen, 1(1), 21-45. https://doi.org/10.20596/maneggio.v1i1.2228

Hermawan, E. (2019). Pengaruh Kompetensi, Pendelegasian Wewenang dan Kepuasan Kerja Terhadap Kinerja. Maneggio: Jurnal Ilmiah Magister Manajemen, 2(2), 148159. https://doi.org/10.20596/maneggio.v2i2.2225

Lisdiani, V., \& Ngatno, N. (2017). PENGARUH PENGEMBANGAN KARIR TERHAD AP KEPUASAN KERJA KARYAWAN MELALUI MOTIVASI KERJA SEBAGAI VARIABEL INTERVENING (STUDI KASUS PADA HOTEL 
GRASIA SEMARANG). Jurnal Ilmu Administrasi Bisnis S1 Undip, 6(4), 105-112.

Nabawi, R. (2019). Pengaruh Lingkungan Kerja, Kepuasan Kerja dan Beban Kerja Terhadap Kinerja Pegawai. Maneggio: Jurnal Ilmiah Magister Manajemen, 2(2), 170182. https://doi.org/10.20596/maneggio.v2i2.2667

Rahmah, R., Semmaila, B., \& Serang, S. (2020). Pengaruh Kompetensi dan Pengembangan Karir Terhadap Kinerja Aparatur Sipil Negara, 2(2), 188-194.

Rosmaini, R., \& Tanjung, H. (2019). Pengaruh Kompetensi, Motivasi Dan Kepuasan Kerja Terhadap Kinerja Pegawai. Maneggio: Jurnal Ilmiah Magister Manajemen, 2(1), 1-15. https://doi.org/10.20596/maneggio.v2i1.2266

Soelton. Muhammad. 2019. How Culture, Training Stand ard and Discipline on the Employee Performance Affect Hotel Management. European Research Studies Journal: Volume XXI, Issue 4 pp. 278-285

https://media.neliti.com/media/publications/225592-menata-pengembangan-karier-sumberdaya-m-e 78b99f7.pdf

http://www.definisi-pengertian.com/2015/07/pengertian-kepuasan-kerja.html 